\title{
Can bioactive peptides of Lagocephalus sceleratus be evaluated in the functional food industry?
}

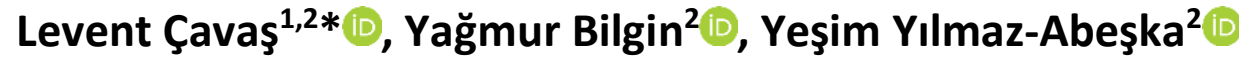

\begin{abstract}
${ }^{1}$ Department of Chemistry, Faculty of Science, Dokuz Eylul University, Kaynaklar Campus, Tinaztepe 35390, Izmir, Turkey.

2Department of Biotechnology, Graduate School of Natural and Applied Sciences, Dokuz Eylul University, Kaynaklar Campus, Tinaztepe 35390, Izmir, Turkey.
\end{abstract}

\section{Article History}

Received 16 November 2020

Accepted 10 December 2020

First Online 11 December 2020

\section{* Corresponding Author}

Tel.: +902323018701

E-mail: levent.cavas@deu.edu.tr

\section{Keywords}

BIOPEP

Bioactive peptides

Functional foods

Lagocephalus sceleratus

\begin{abstract}
Observations of Lessepsian migrant Lagocephalus sceleratus has been increasing along the Turkish coastline. Because of its toxins, it is known as a poisonous fish and not recommended to consume. To overcome this problem, an in silico-based biotechnological approach is proposed to evaluate the bioactive peptides from this species. The bioactive peptide contents of cytochrome oxidase subunit 1 in $L$. sceleratus with BIOPEP parameters were investigated in this study. The results show that there are many bioactive peptides such as the peptides with DPP-IV, ACE, alphaglucosidase inhibition activities, antioxidant and antiamnestic and their levels are comparable in well-consumed species such as Gallus gallus domesticus and Bos taurus. In conclusion, after removal of the toxin, the biomass of the $L$. sceleratus can be used to produce bioactive peptides for the production of functional foods which will be very important for food industry to provide multi-functional properties to foods. The paper can be used as a model methodology to exploit new bioactive peptides when new proteins are explored from $L$. sceleratus.
\end{abstract}

\section{Introduction}

Introduction of invasive species into the new ecosystem creates important problems on the indigenous species. The Mediterranean Sea is under threat of introduction of invasive species due to the Suez Channel and also heavy maritime traffic (Galil, 2009). Although Lagocephalus sceleratus (Gmelin, 1789) is a very common species in the tropical waters such as Indian and Pacific Ocean, it is being one of the well invaded species in the Mediterranean Sea via Suez Channel (Leonardo et al, 2019). This alien fish has been commonly observed in almost all the Mediterranean Sea region (Akyol et al., 2005; Kalogirou, 2013; Kasapidis et al., 2007). Since this species has poisonous compounds in its tissues, it is not under stress of human consumption and fisheries (Leonardo et al, 2019). Therefore, this species has increased its habitat along the Mediterranean Sea. The scientific reports and also observations by fishermen revealed that this species consumes the eggs of local fish species and destroys the fisheries in the Mediterranean Sea (Kalogirou, 2013; Yaglioglu et al., 2011). According to Ulman et al. (2015), while $5 \%$ of fish caught in 2003 were L. sceleratus, this increased up to $50 \%$ after 5 years. L. sceleratus is a successful invasive species as it has a high reproduction rate, can hunt natural predators, benefit from food resources and adapt well to environmental conditions (Yaglioglu et al., 2011). They can reach $15-60 \mathrm{~cm}$ in length and mostly live at depths of 18-100 m (Yaglıoglu et al., 2011). L. sceleratus is very difficult to be hunted by its predators since it can inflate itself with the water and air in the environments and is highly poisonous (Golani et al., 2006). L. sceleratus includes tetrodotoxin (TTX) and this toxin is considered as one of the most effective chemicals among the marine toxins. Since no developed antidote or antitoxin related to TTX is existed, it is very dangerous to touch or consume L. sceleretus. 
According to scientific publications, L. sceleratus in the Mediterranean Sea also includes the toxin at lethal doses (Bentur et al., 2008). As the fish grows in size, its toxicity increases (Katikou et al., 2009). Katikou et al. (2009) reported that while liver, gastrointestinal system and gonads had the highest level of toxicity in all of their samples, the toxicity in muscles and tissues was lower. The toxicity distribution is species-specific, but within the same species, local, seasonal and individual variations and also variations in toxin composition are observed (Katikou et al., 2009; Noguch \& Arakawa, 2008; Yu \& Yu; 2002). Kosker et al. (2019) investigated TTX levels in different $L$. sceleratus and found the TTX level in tissues in the range of $0.69-35.6 \mu \mathrm{g} / \mathrm{g}$ and most in gonad and liver tissues.

TTX is used as a channel blocker in physiological and neurological studies in many laboratories (Narahashi, 2001; Saoudi et al., 2010). TTX has an analgesic effect in advanced patients, shows an antitumor effect and is used for the treatment of drug addiction (Bragadeeswaran et al., 2010; Haque et al., 2008; Saoudi et al., 2010; Schwartz et al., 1998; Yu, 2008). Also, TTX is used for rheumatism treatments in Japan (Noguchi \& Arakawa, 2008). Due to the possible inhibitory effect of TTX on neural conduction, it is examined for developing anesthetic drugs (Schwartz et al., 1998).

Food derived bioactive peptides are the hot research topics in functional food industry. Bioactive peptides are important sources for essential amino acids, and they have biological activities such as antioxidant, antimicrobial, antihypertensive, anticancer and antihyperglycemic (Karami et al., 2019; Tonolo et al., 2020; Valencia-Mejía et al., 2019; Zhou et al., 2020). Bioactive peptides can be obtained through the enzymatic hydrolysis, fermentation or food processing (Liu et al., 2020). Most of the bioactive peptides consist of 2-20 amino acids and they display different activities based on their amino acid compositions and secondary structures (Bechaux et al., 2019; Ryan et al., 2011). Bioactive peptides have been classified via in silico or in vitro studies from dairy products, mushroom, fish, meat, and seaweed etc. (Barati et al, 2020; Cipolari et al., 2020; Lafarga et al., 2020; Sayd et al., 2018; Zhou et al., 2020). The number of bioactive peptides according to BIOPEPUWM is 4056 and this number is increasing with the new studies (Minkiewicz et al., 2019). Since they are easily absorbed in the intestine and can go into the circulatory system, they can exhibit physiological effects (MartínezSánchez et al., 2020). Moreover, bioactive peptides have been the subject of research in the development of functional foods and medicines (Jauset \& Beaulieu, 2019; Tadesse \& Emire, 2020). Fish based bioactive peptides are reviewed by Cipolari et al. (2020). They underlined that fish venoms and poisons are still undiscovered resources for bioactive peptides.

In this study, we aimed to investigate bioactive content of $L$. sceleratus by selecting a model protein (cytochrome c oxidase subunit 1) and then the results of
L. sceleratus were compared with the traditional protein sources. This model biotechnological method proposes a novel in silico approach to evaluate the biomass of $L$. sceleratus.

\section{Methods}

The proteins were searched by using the keyword "Lagocephalus sceleratus" in Uniprot.org (The UniProt Consortium, 2019). 45 entries were found in uniprot.org related to $L$. sceleratus. From the entries, it is understood that they are unreviewed that means "records that await full manual annotation" according to Uniprot.org. The min and max length of amino acids in the entries were found in major capsid protein and $\mathrm{NADH}$-ubiquinone oxidoreductase chain 5 (EC 7.1.1.2) to be 51 and 612, respectively. Cytochrome c oxidase subunit 1 was selected as a model protein for our research due to i) it contains relatively high number of amino acids, ii) it is also found in well-consumed animal sources such as bovine (Bos taurus) and chicken (Gallus gallus domesticus), iii) it is an important protein in electron transport chain. Bovine and chicken sequences were selected for comparison purposes. Moreover, this protein is one of the vital components of the mitochondria. The catalytic activity is based on the electron transfer and it catalyzes the reduction of oxygen to water via reduced cytochrome c. The aim of this report is to exhibit a model study for $L$. sceleratus. When new proteins from this fish species are discovered, bioactive peptide contents can be identified by using this methodology. The flowchart of the study was given in Figure 1.

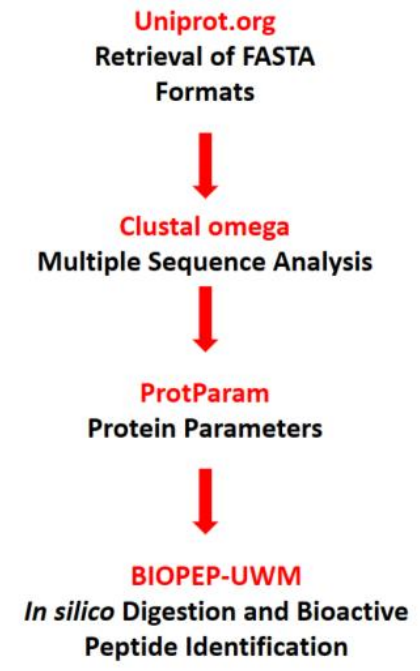

Figure 1. Flowchart of the methodology.

Amino acid sequence in FASTA format of cytochrome c oxidase subunit 1 protein found in Lagocephalus sceleratus (F2EN11), Bos taurus (P00396) and Gallus gallus (P18943) were retrieved from Uniprot.org (The UniProt Consortium, 2019; Morgat et al., 2019).

Multiple sequence analysis of cytochrome c oxidase proteins was performed using Clustal omega 
(Sievers et al., 2011). The similarity between sequences and preserved regions were shown by using the outputs of Clustal omega.

ProtParam tool was used for defining the physical and chemical characteristics of studied proteins (Gasteiger et al., 2005). Molecular weight, percentage and number of amino acids, instability index, net charge and theoretical pl value were determined via this tool.

Bioactive peptides found in $L$. sceleratus were investigated using BIOPEP-UWM database (Minkiewicz et al., 2019). Chymotrypsin, trypsin and pepsin ( $\mathrm{pH}=1.3)$ enzymes were used for in silico digestion of the proteins studied in the report. These enzymes were chosen in the study because they are involved in the gastrointestinal track of humans. Cytochrome $c$ oxidase proteins of $B$. taurus and $G$. gallus domesticus were also in silico digested by using the same methodology in the present study.

\section{Results}

Clustal omega database was used for determining the similarity between Lagocephalus sceleratus, Bos taurus and Gallus gallus domesticus. The asterisk symbol $(*)$ shows conserved residues while colons (:) indicates groups with similar characteristics and period (.) shows groups with little similar characteristics. The comparisons between cytochrome c oxidase subunit 1 proteins of $L$. sceleratus, $B$. taurus and $G$. gallus domesticus can be seen in Figure 2a-b. The multiple sequence analysis results of the cytochrome $c$ oxidase subunit 1 proteins found in L. sceleratus, B. taurus and G. gallus domesticus were shown in Figure 2a-b. From Figure $2 a$ and $b$, it could be said that there is very high similarity among these species.

Physical and chemical characteristics of cytochrome c oxidase subunit 1 proteins found in $L$. sceleratus, B. taurus and G. gallus domesticus were determined by using ProtParam tool (Gasteiger et al.,
2005). According to Table 1 , most abundant amino acids found in cytochrome $c$ oxidase subunit 1 protein of $L$. sceleratus are leucine, alanine and glycine to be 12.10 , 9.20 , and $9.10 \%$, respectively. There is a similar order for the number of amino acids found in cytochrome $c$ oxidase subunit 1 proteins of $B$. taurus and G. gallus domesticus. The theoretical $\mathrm{pl}$ values of cytochrome $\mathrm{C}$ oxidase proteins found in L. sceleratus and G. gallus domesticus were found nearly the same as 6.21 and 6.23 (Table 2).

Table 1. Number and percentage of amino acids found in cytochrome c oxidase subunit 1 proteins of Lagocephalus sceleratus, Bos taurus and Gallus gallus domesticus

\begin{tabular}{ccccccc}
\hline & \multicolumn{2}{c}{$\begin{array}{c}\text { Lagocephalus } \\
\text { sceleratus }\end{array}$} & \multicolumn{2}{c}{$\begin{array}{c}\text { Gallus } \\
\text { domesticus }\end{array}$} & \multicolumn{2}{c}{ Bos taurus } \\
\cline { 2 - 7 } & $\#$ & $\%$ & $\#$ & $\%$ & $\#$ & $\%$ \\
\hline Ala (A) & 48 & 9.20 & 46 & 8.90 & 40 & 7.80 \\
Arg (R) & 9 & 1.70 & 9 & 1.70 & 8 & 1.60 \\
Asn (N) & 14 & 2.70 & 15 & 2.90 & 19 & 3.70 \\
Asp (D) & 14 & 2.70 & 15 & 2.90 & 16 & 3.10 \\
Cys (C) & 1 & 0.20 & 1 & 0.20 & 1 & 0.20 \\
Gln (Q) & 7 & 1.30 & 9 & 1.70 & 6 & 1.20 \\
Glu (E) & 12 & 2.30 & 10 & 1.90 & 9 & 1.80 \\
Gly (G) & 47 & 9.10 & 46 & 8.90 & 47 & 9.10 \\
His (H) & 21 & 4.00 & 19 & 3.70 & 17 & 3.30 \\
Ile (I) & 37 & 7.10 & 41 & 8.00 & 37 & 7.20 \\
Leu (L) & 63 & 12.10 & 62 & 12.00 & 59 & 11.50 \\
Lys (K) & 9 & 1.70 & 9 & 1.70 & 9 & 1.80 \\
Met (M) & 27 & 5.20 & 26 & 5.00 & 34 & 6.60 \\
Phe (F) & 42 & 8.10 & 43 & 8.30 & 42 & 8.20 \\
Pro (P) & 28 & 5.40 & 31 & 6.00 & 28 & 5.40 \\
Ser (S) & 28 & 5.40 & 26 & 5.00 & 30 & 5.80 \\
Thr (T) & 37 & 7.10 & 40 & 7.80 & 38 & 7.40 \\
Trp (W) & 17 & 3.30 & 17 & 3.30 & 17 & 3.30 \\
Tyr (Y) & 18 & 3.50 & 18 & 3.50 & 19 & 3.70 \\
Val (V) & 40 & 7.70 & 32 & 6.20 & 38 & 7.40 \\
\hline & & & & & &
\end{tabular}

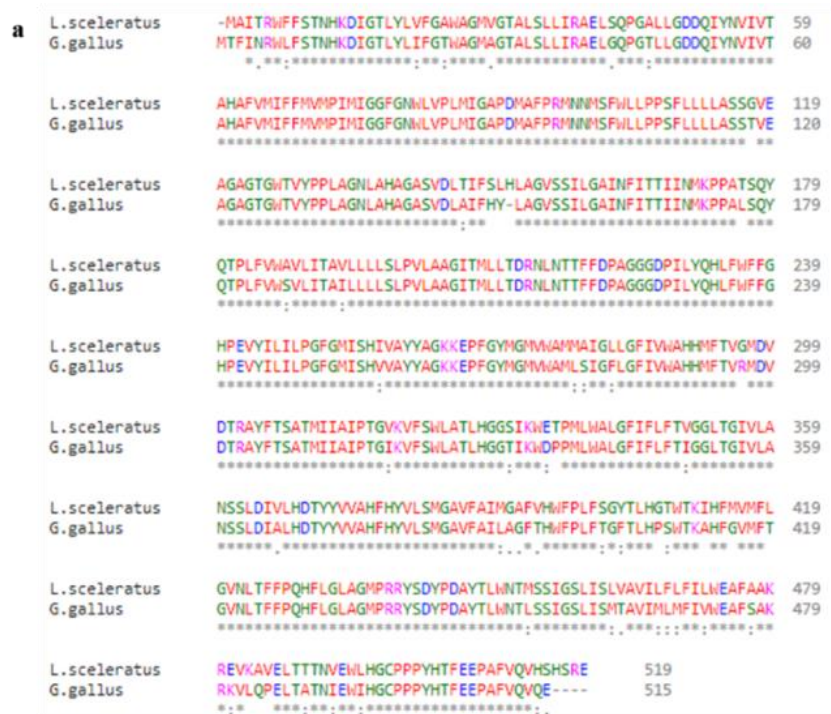

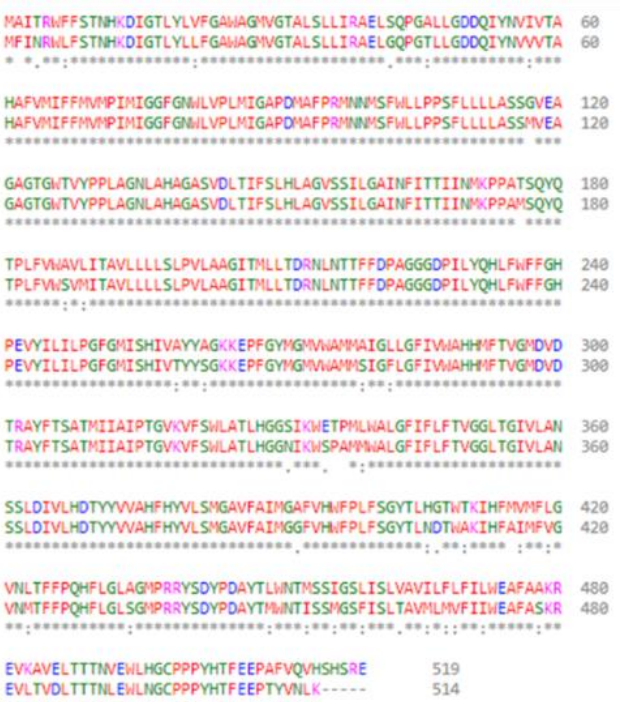

EVLTVDLTTTMLENLNGCPPPYHTFEEPTYMLK - -

Figure 2. Multiple sequence analysis of (a) Lagocephalus sceleratus and Gallus gallus domesticus (b) Lagocephalus sceleratus and Bos taurus. 
Table 2. Protein parameters of cytochrome c oxidase subunit 1 proteins found in Lagocephalus sceleratus, Bos taurus and Gallus gallus domesticus (aa: amino acids)

\begin{tabular}{cccccccc}
\hline Species & \# aa & $\begin{array}{c}\text { Mw } \\
\text { (Kda) }\end{array}$ & $\begin{array}{c}\text { Theoretical } \\
\text { pl }\end{array}$ & $\begin{array}{c}\text { Negatively } \\
\text { Charged Residues } \\
\text { (Asp+Glu) }\end{array}$ & $\begin{array}{c}\text { Positively } \\
\text { Charged Residues } \\
\text { (Arg+Lys) }\end{array}$ & $\begin{array}{c}\text { Net } \\
\text { Charge }\end{array}$ & $\begin{array}{c}\text { Instability } \\
\text { Index }\end{array}$ \\
\hline Lagocephalus sceleratus & 519 & 57314.59 & 6.21 & 26 & 18 & -8 & 26.54 \\
Gallus gallus domesticus & 515 & 57051.23 & 6.23 & 25 & 18 & -7 & 29.60 \\
Bos taurus & 514 & 57032.31 & 6.06 & 25 & 17 & -8 & 25.81 \\
\hline
\end{tabular}

The net charge of cytochrome c oxidase subunit 1 protein of $L$. sceleratus was found to be -8 while cytochrome c oxidase proteins of $B$. taurus and $G$. gallus domesticus were determined as -7 and -8 , respectively. Instability index is a value that corresponds to the stability of the protein found in the test tube. Protein is stable when the stability index is below 40 (Guruprasad et al., 1990). According to Table 2, the instability index of cytochrome c oxidase proteins found in L. sceleratus is 26.54 and other studied proteins have similar instability index values.

Table 3. In silico hydrolysis of cytochrome c oxidase subunit 1 protein of Lagocephalus sceleratus using BIOPEP-UWM database (CaMPDE: Calmodulin-dependent phosphodiesterase 1; ACE: Angiotensin Converting Enzyme)

\begin{tabular}{|c|c|c|c|c|c|}
\hline \multicolumn{6}{|c|}{$\begin{array}{l}\mathrm{DH}_{\mathrm{t}}[\%] \\
35.1393\end{array}$} \\
\hline No & Activity & $A_{E}$ & $\mathbf{w}$ & $\mathbf{B}_{\mathrm{E}}$ & $\mathbf{v}$ \\
\hline 1 & Antiamnestic & 0.0015 & 0.3261 & $3.28850 \mathrm{E}-5$ & 1 \\
\hline 2 & Inhibitor & 0.0015 & 1.0000 & 0 & \\
\hline 3 & $\begin{array}{c}\text { ACE } \\
\text { inhibitor }\end{array}$ & 0.0495 & 0.1266 & 0.00404 & 0.14986 \\
\hline 4 & Stimulating & 0.0077 & 0.1158 & 0 & \\
\hline 5 & Antioxidative & 0.0108 & 0.1247 & 0 & 0 \\
\hline 6 & $\begin{array}{c}\text { Renin } \\
\text { inhibitor }\end{array}$ & 0.0062 & 0.2672 & 0.00017 & 0.98743 \\
\hline 7 & $\begin{array}{l}\text { CaMPDE } \\
\text { inhibitor }\end{array}$ & 0.0015 & 1.0000 & 0 & \\
\hline 8 & $\begin{array}{l}\text { Dipeptidyl } \\
\text { peptidase IV } \\
\text { inhibitor }\end{array}$ & 0.0634 & 0.1100 & 0.00013 & 0.21510 \\
\hline 9 & $\begin{array}{l}\text { Alpha- } \\
\text { glucosidase } \\
\text { inhibitor }\end{array}$ & 0.0031 & 0.1179 & 0.00014 & 0.65774 \\
\hline 10 & $\begin{array}{c}\text { Dipeptidyl } \\
\text { peptidase III } \\
\text { inhibitor }\end{array}$ & 0.0124 & 0.1542 & 0 & \\
\hline
\end{tabular}

In silico hydrolysis of studied proteins were performed using BIOPEP-UWM tool and chymotrypsin, trypsin and pepsin $(\mathrm{pH}=1.3)$ enzymes were used. $\mathrm{DH}_{\mathrm{t}}$ value is a theoretical degree of hydrolysis and in this study $\mathrm{DH}_{\mathrm{t}}$ value of cytochrome $\mathrm{c}$ oxidase subunit 1 proteins found in L. sceleratus is 35.1393 (Table 3). $A_{E}$ value corresponds to the frequency of release of fragments by selected enzymes (Minkiewicz et al., 2019). According to Table 3, $A_{E}$ value was found for dipeptidyl peptidase IV inhibitor as 0.0634, ACE (Angiotensin-converting enzyme) inhibitor as 0.0495 and dipeptidyl peptidase III inhibitor as 0.0124. Similar activities and $A_{E}$ values were obtained with the hydrolysis of cytochrome c oxidase proteins of $B$. taurus and G. gallus domesticus (Table 4-5).
Table 4. In silico hydrolysis of cytochrome c oxidase protein of Gallus gallus domesticus using BIOPEP-UWM database (CaMPDE: Calmodulin-dependent phosphodiesterase 1; ACE: Angiotensin Converting Enzyme)

\begin{tabular}{cccccc}
\hline $\begin{array}{c}\mathrm{DH}_{\mathrm{t}}[\%] \\
35.1823\end{array}$ & & & & & \\
\hline $\mathbf{N o}$ & Activity & $\mathbf{A}_{\mathrm{E}}$ & $\mathbf{W}$ & $\mathbf{B}_{\mathrm{E}}$ & $\mathbf{V}$ \\
\hline $\mathbf{1}$ & $\begin{array}{c}\text { Immunostimulating } \\
\mathbf{2}\end{array}$ & 0.0016 & 0.5000 & 0 & \\
$\mathbf{3}$ & $\begin{array}{c}\text { Antiamnestic } \\
\text { ACE } \\
\text { inhibitor }\end{array}$ & 0.0016 & 0.3404 & $3.36655 \mathrm{E}-5$ & 1 \\
$\mathbf{4}$ & $\begin{array}{c}\text { Stimulating } \\
\mathbf{5}\end{array}$ & 0.0522 & 0.1320 & 0.00382 & 0.13687 \\
$\mathbf{6}$ & $\begin{array}{c}\text { Antioxidative } \\
\text { renin } \\
\text { inhibitor }\end{array}$ & 0.0127 & 0.1280 & 0 & \\
$\mathbf{7}$ & $\begin{array}{c}\text { CaMPDE } \\
\text { inhibitor }\end{array}$ & 0.0079 & 0.2500 & 0.00017 & 0.98746 \\
$\mathbf{8}$ & $\begin{array}{c}\text { Dipeptidyl } \\
\text { peptidase IV } \\
\text { inhibitor }\end{array}$ & 0.0633 & 0.1102 & 0.00018 & 0.29338 \\
$\mathbf{9}$ & $\begin{array}{c}\text { Alpha-glucosidase } \\
\text { inhibitor } \\
\text { Dipeptidyl }\end{array}$ & 0.0032 & 0.1190 & 0.00014 & 0.49511 \\
$\mathbf{1 0}$ & $\begin{array}{c}\text { peptidase III } \\
\text { inhibitor }\end{array}$ & 0.0142 & 0.1547 & 0 & \\
\hline & & & & & \\
\hline
\end{tabular}

Table 5. In silico hydrolysis of cytochrome c oxidase protein of Bos taurus using BIOPEP-UWM database (CaMPDE: Calmodulin-dependent phosphodiesterase 1; ACE: Angiotensin Converting Enzyme)

\begin{tabular}{|c|c|c|c|c|c|}
\hline \multicolumn{6}{|c|}{$\begin{array}{l}\mathrm{DH}_{\mathrm{t}}[\%] \\
36.2041 \\
\end{array}$} \\
\hline No & Activity & $A_{E}$ & w & $B_{E}$ & $\mathbf{v}$ \\
\hline 1 & Antiamnestic & 0.0016 & 0.3333 & $3.38799 \mathrm{E}-5$ & 1 \\
\hline 2 & Inhibitor & 0.0016 & 1.0000 & 0 & \\
\hline 3 & $\begin{array}{c}\text { ACE } \\
\text { inhibitor }\end{array}$ & 0.0478 & 0.1261 & 0.00391 & 0.14212 \\
\hline 4 & Stimulating & 0.0064 & 0.1087 & 0 & \\
\hline 5 & Antioxidative & 0.0096 & 0.1257 & 0 & 0 \\
\hline 6 & $\begin{array}{c}\text { Renin } \\
\text { inhibitor }\end{array}$ & 0.0064 & 0.3092 & 0.00017 & 0.98743 \\
\hline 7 & $\begin{array}{l}\text { CaMPDE } \\
\text { inhibitor }\end{array}$ & 0.0016 & 1.0000 & 0 & \\
\hline 8 & $\begin{array}{l}\text { Dipeptidyl } \\
\text { peptidase IV } \\
\text { inhibitor } \\
\text { Alpha- }\end{array}$ & 0.0621 & 0.1068 & 0.00013 & 0.20641 \\
\hline 9 & $\begin{array}{l}\text { glucosidase } \\
\text { inhibitor } \\
\text { Dipeptidyl }\end{array}$ & 0.0032 & 0.1339 & 0.00014 & 0.65819 \\
\hline 10 & $\begin{array}{c}\text { peptidase III } \\
\text { inhibitor }\end{array}$ & 0.0127 & 0.1564 & 0 & \\
\hline
\end{tabular}

\section{Discussion}

The importance of bioactive peptides is being increased since the several health effects of bioactive peptides are shown in numerous papers. Bioactive peptides occur via enzymatic catalysis, digestion in 
gastrointestinal track or fermentation via several microorganisms (Chalamaiah et al, 2018; Gorguç et al., 2020). Bioactive peptides are generally characterized via wet lab studies. On the other hand, in silico tools developed under the umbrella of bioinformatics have been providing significant contributions to wet-lab studies and also, they have been accelerating the discoveries of novel bioactive peptides. One of the most important and well known in silico tools is found in BIOPEP-UWM Database. (Minkiewich et al., 2019). By using BIOPEP-UWM Database, several bioactive peptides such as ACE inhibitor, activating ubiquitinmediated proteolysis, alpha-glucosidase inhibitor, antiviral, dipeptidyl peptidase IV inhibitor, heparin binding, HMG-CoA reductase inhibitor, Protein Kinase C inhibitor and vasoconstrictor can be obtained under in silico conditions. More activities are listed by Minkiewich et al. (2019). The tool provides scientists to compare the protein sources efficiently before wet-lab conditions. From this perspective, the bioactive peptide contents of cytochrome c oxidase subunit 1 from invasive $L$. sceleratus are compared with cytochrome $c$ oxidase subunit 1 from Bos taurus and Gallus gallus domesticus.

Red meat consumption is becoming very problematic due to many factors such as the contribution to increased emission of greenhouse gases, environmental pollution problems and also health problems caused by processed meat products (Gonzales et al., 2020). Instead of increasing red meat consumption from terrestrial livestocks, the use of Lagocephalus sceleratus may provide an alternative source after removal of its toxin.

In this study, protein parameters of cytochrome c oxidase subunit 1 protein from $L$. sceleratus were compared with $G$. gallus domesticus and B. taurus. From the results, it could be said that essential amino acids are almost same levels in these species. Therefore, $L$. sceleratus could be used to supply essential amino acid resources for functional food industry. However, it is important to note that the toxin should be removed before use of the bioactive peptides or the essential amino acids from $L$. sceleratus. The concentration of TTX varies based on many different factors such as season, length and also organs (Kosker et al., 2016; Kosker et al., 2019). Therefore, optimized conditions should be developed before utilization of the bioactive peptides from this alien species in the Mediterranean Sea.

The model protein, cytochrome oxidase subunit 1 , from $L$. sceleratus was hydrolyzed in the study by using digestion enzymes such as chymotrypsin, trypsin and pepsin. Many bioactive peptides such as antiamnestic, inhibitor, ACE inhibitor, stimulating, antioxidative, renin inhibitor, Calmodulin-dependent phosphodiesterase 1 (CaMPDE) inhibitor, dipeptidyl peptidase IV inhibitor, alpha-glucosidase inhibitor, dipeptidyl peptidase III inhibitor were obtained after in silico hydrolysis. The results were also compared with $B$. taurus and also $G$. gallus domesticus (Table 3-5).
Although we observe slightly increased $\mathrm{DHt}(\%)$ in $B$. taurus, the values of $L$. sceleratus and $G$. gallus domesticus were very close. It is very interesting to note that $A_{E}$ value related to $A C E$ inhibition in $G$. gallus domesticus was significantly higher than those of other studied animals in the study. Stimulating bioactive peptides are defined as the peptides that stimulate various biological processes. Since the values of $G$. gallus domesticus and $L$. sceleratus were very close, $L$. sceleratus can be used as an alternative source for $G$. gallus domesticus. Antioxidant property of $L$. sceleratus showed similar trend, AE value was very close to $G$. gallus domesticus, on the other hand, it was higher than that of $B$. taurus. Since there are many well defined antioxidant molecules in scientific literature, antioxidant property of an industrial food component can be supplied from different plant based sources. Reninangiotensin system (RAS) has important physiological role for blood pressure and related homeostasis (Crowley et al., 2012). Increased activity of renin is associated with elevated blood pressure (Fu et al., 2017). Renin inhibitor property of $L$. sceleratus was found to be close to $B$. taurus, on the other hand, it was lower than that of $G$. gallus domesticus.

The bioactive peptides with CaMPDE inhibitor property may be of importance in the diseases associated with excessive inflammatory signaling since CaMPDE plays critical roles in cyclic nucleotide metabolism (O'Brien et al., 2020). Obtaining similar values compared to $G$. gallus and $B$. taurus might show the importance of $L$. sceleratus.

For example, DPP-IV is one of the target enzymes in the therapy of Type II Diabetes. Its inhibition increases the insulin stimulation (Craddy et al., 2014). Similar inhibition parameters were found within degraded protein of $L$. sceleratus confirms that the isolated bioactive peptides (TTX-free) from this alien can be proposed for consumption in diabetes therapy. Another medicinally important enzyme is ACE. This enzyme is associated with hypertension and its inhibition may provide a contribution to the therapy of hypertension. We also observed that ACE inhibitor property is also existed in the results (Table 3 ).

Alpha-glucosidase inhibition is an important topic in therapeutic approaches for diabetes mellitus due to involvement of alpha-glucosidase in the digestion of dietary starch into glucose (Papoutsis et al., 2020). The $\mathrm{A} E$ values related to alpha-glucosidase inhibition were found quite similar. Therefore, it could be said that there is no difference among the species studied in this study for alpha-glucosidase inhibition.

At first glance, it could be thought that use of this alien species for the Mediterranean Sea could be dangerous due to TTX. On the other hand, several studies reveal that the tissues of the fish even with TTX may be used for the treatment of various diseases.

In an interesting study carried by Hong et al (2018), it is shown that oral TTX pellets inhibited resiniferatoxininduced postherpetic neuralgia in a rat model. TTX was 
also reported as an analgesic for various pains and also cancer (Nieto et al., 2012). TTX combined with lidocaine is also proposed for severe arrhythmias by Hong et al. (2019). From these publications, it could be inferred that bioactive pellets including bioactive peptides mentioned in this study can be exploited in these diseases.

As it is mentioned in the materials section, limited numbers of protein sequences exist in the protein databases related to $L$. sceleratus. Liver and gonads of this species may include novel proteins and also novel bioactive peptides. After wet lab-based techniques such as $2 \mathrm{D}$-electrophoresis, the novel proteins in this fish can be explored. After sequence analysis, enzymatically digested proteins can be studied in silico and in vitro to understand their functional properties. However, it must be noted that TTX should be removed from $L$. sceleratus based products for possible human consumption because of its toxic effects on human metabolism. Alternatively, TTX containing formulas like in Hong et al. 2018 and Hong et al. 2019 may be prepared to evaluate the biomass of the species (for therapeutic purposes).

\section{Conclusion}

Observation of L. sceleratus in the Mediterranean coastline of Turkey has been in increasing trend. Since no human consumption is proposed due to its highly effective toxin, an alternative utilization method should be proposed to create a stress on the $L$. sceleratus population. The present paper reveals that there are many bioactive peptides and their BIOPEP parameters are in comparable levels with well-consumed $B$. taurus and G. gallus domesticus. Moreover, TTX have been recently associated with promising therapeutic effects (Hong et al., 2018; Hong et al., 2019; Nieto et al., 2012). Therefore, more wet lab-based studies are strongly recommended to exploit the idea on the utilization of widely distributed L. sceleratus in the Mediterranean Sea.

\section{References}

Akyol, O., Unal, V., Ceyhan, T., \& Bilecenoglu, M. (2005). First confirmed record of Lagocephalus sceleratus (Gmelin, 1789 ) in the Mediterranean Sea. Journal of Fish Biology, 66, 1183-1186.

Barati, M., Javanmardi, F., Jabbari, M., Mokari-Yamchi, A., Farahmand, F., Eş, I., Farhadnejad H., Davoodi S. H., \& Khaneghah, A. M. (2020). An in silico model to predict and estimate digestion-resistant and bioactive peptide content of dairy products: A primarily study of a timesaving and affordable method for practical research purposes. LWT - Food Science and Technology, 130, 109616, $1-12$.

Bechaux, J., Gatellier, P., Le Page, J. F., Drillet, Y., \& SanteLhoutellier, V. (2019). A comprehensive review of bioactive peptides obtained from animal byproducts and their applications. Food \& Function, 10(10), 6244-6266.
Bentur, Y., Ashkar, J., Lurie, Y., Levy, Y., Azzam, Z. S., Litmanovich, M., Golik M., Gurevych B., Golani D., \& Eisenman, A. (2008). Lessepsian migration and tetrodotoxin poisoning due to Lagocephalus sceleratus in the eastern Mediterranean. Toxicon, 52(8), 964-968.

Bragadeeswaran, S., Therasa, D., Prabhu, K., \& Kathiresan, K. (2010). Biomedical and pharmacological potential of tetrodotoxin-producing bacteria isolated from marine pufferfish Arothron hispidus (Muller, 1841). Journal of Venomous Animals and Toxins Including Tropical Diseases, 16(3), 421-431.

Chalamaiah, M., Yu, W., \& Wu, J. (2018). Immunomodulatory and anticancer protein hydrolysates (peptides) from food proteins: A review. Food Chemistry, 245, 205-222.

Cipolari, O. C., de Oliveira Neto, X. A. \& Conceição, K. (2020). Fish bioactive peptides: A systematic review focused on sting and skin. Aquaculture, 515, 734598.

Craddy, P., Palin, H. J., \& Johnson, K. J. (2014). Comparative Effectiveness of Dipeptidyl peptidase- 4 Inhibitors in Type 2 Diabetes: A Systematic Review and Mixed Treatment Comparison. Diabetes Therapy. 5, 1- 41.

Crowley, S. D., \& Coffman, T. M. (2012). Recent advances involving the renin-angiotensin system. Experimental Cell Research, 318(9), 1049-1056.

Fu, Y., Alashi, A. M., Young, J. F., Therkildsen, M., \& Aluko, R. E. (2017). Enzyme inhibition kinetics and molecular interactions of patatin peptides with angiotensin Iconverting enzyme and renin. International Journal of Biological Macromolecules, 101, 207-213.

Galil, B. S. (2009). Taking stock: inventory of alien species in the Mediterranean Sea. Biological Invasions, 11(2), 359-372.

Gasteiger, E., Hoogland, C., Gattiker, A., Wilkins, M. R., Appel, R. D., \& Bairoch, A. (2005). Protein identification and analysis tools on the ExPASy server. In The proteomics protocols handbook, 571-607. Humana press.

Golani, D., Ozturk, B., \& Basusta, N. (2006). Fishes of the Eastern Mediterranean-Turkish Marine Research Foundation (Publication No. 24). Istanbul, Turkey.

González, N., Marquès, M., Nadal, M., \& Domingo, J. L. (2020). Meat consumption: which are the current global risks? A review of recent (2010-2020) evidences. Food Research International, 109341.

Gorguc, A., Gencdag, E., \& Yilmaz, F. M. (2020). Bioactive peptides derived from plant origin by-products: Biological activities and techno-functional utilizations in food developments-A review. Food Research International, 109504.

Guruprasad, K., Reddy, B. V. B., \& Pandit, M. W. (1990). Correlation between stability of a protein and its dipeptide composition: a novel approach for predicting in vivo stability of a protein from its primary sequence. Protein Engineering, Design and Selection. 4,155-161.

Haque, M. A., Islam, Q. T., Razzak, M. A., Faiz, M. A., \& Bari, M. I. (2008). Neurological Manifestations of Puffer Fish Poisoning and Its Outcome: Study of 83 Cases. TAJ: Journal of Teachers Association, 21(2), 121-125.

Hong, B., He, J., Le, Q., Bai, K., Chen, Y., \& Huang, W. (2019). Combination Formulation of Tetrodotoxin and Lidocaine as a Potential Therapy for Severe Arrhythmias. Marine Drugs, 17(12), 685.

Hong, B., Sun, J., Zheng, H., Le. Q., Wang, C., Bai, K., He, J., He, H., \& Dong, Y. (2018). Effect of tetrodotoxin pellets in a rat model of postherpetic neuralgia. Marine Drugs, 16(6), 195. 
Jauset, T., \& Beaulieu, M. E. (2019). Bioactive cell penetrating peptides and proteins in cancer: a bright future ahead. Current Opinion in Pharmacology, 47, 133-140.

Kalogirou, S. (2013). Ecological characteristics of the invasive pufferfish Lagocephalus sceleratus (Gmelin, 1789) in Rhodes, Eastern Mediterranean Sea. A case study. Mediterranean Marine Science, 14, 251-260.

Karami, Z., Peighambardoust, S. H., Hesari, J., Akbari-Adergani, B., \& Andreu, D. (2019). Antioxidant, anticancer and ACEinhibitory activities of bioactive peptides from wheat germ protein hydrolysates. Food Bioscience, 32, 100450.

Kasapidis, P., Peristeraki, P., Tserpes G., \& Magoulas A. (2007). First record of the Lessepsian migrant Lagocephalus sceleratus (Gmelin 1789) (Osteichthyes: Tetraodontidae) in the Cretan Sea (Aegean, Greece). Aquatic Invasions, 1, 71-73.

Katikou, P., Georgantelis, D., Sinouris, N., Petsi, A., \& Fotaras, T. (2009). First report on toxicity assessment of the Lessepsian migrant pufferfish Lagocephalus sceleratus (Gmelin, 1789) from European waters (Aegean Sea, Greece). Toxicon, 54(1), 50-55.

Kosker, A. R., Ozogul, F., Ayas, D., Durmus, M., Ucar, Y., Regenstein, J. M., \& Ozogul, Y. (2019). Tetrodotoxin levels of three pufferfish species (Lagocephalus sp.) caught in the North-Eastern Mediterranean Sea. Chemosphere, 219, 95-99.

Kosker, A. R., Ozogul, F., Durmus, M., Ucar, Y., Ayas, D., Regenstein, J. M., \& Ozogul, Y. (2016). Tetrodotoxin levels in pufferfish (Lagocephalus sceleratus) caught in the Northeastern Mediterranean Sea. Food Chemistry, 210, 332-337.

Lafarga, T., Acién-Fernández, F. G., \& Garcia-Vaquero, M. (2020). Bioactive peptides and carbohydrates from seaweed for food applications: Natural occurrence, isolation, purification, and identification. Algal Research, 48, 101909.

Leonardo, S., Kiparissis, S., Rambla-Alegre, M., Almarza, S., Roque, A., Andree, K. B., Christidis A., Flores C., Campbell K., Elliott, C. T., Aligizaki K., Diogéne J., \& Campàs M., (2019). Detection of tetrodotoxins in juvenile pufferfish Lagocephalus sceleratus (Gmelin, 1789) from the North Aegean Sea (Greece) by an electrochemical magnetic bead-based immunosensing tool. Food Chemistry, 290, 255-262.

Liu, L., Li, S., Zheng, J., Bu, T., He, G., \& Wu, J. (2020). Safety considerations on food protein-derived bioactive peptides. Trends in Food Science \& Technology, 96, 199207.

Martínez-Sánchez, S. M., Gabaldón-Hernández, J. A., \& Montoro-García, S. (2020). Unravelling the molecular mechanisms associated with the role of food-derived bioactive peptides in promoting cardiovascular health. Journal of Functional Foods, 64, 103645.

Minkiewicz, P., Iwaniak, A., \& Darewicz, M. (2019). BIOPEPUWM database of bioactive peptides: Current opportunities. International Journal of Molecular Sciences, 20(23), 5978.

Morgat, A., Lombardot, T., Coudert, E., Axelsen, K., Neto, T. B., Gehant, S., Bansal, P., Bolleman, J., Gasteiger, E., de Castro, E., Baratin, D., Pozzato, M., Xenarios, I., Poux, S., Redaschi, N., Bridge, A., \& The UniProt Consortium (2019). Enzyme annotation in UniProtKB using Rhea. Bioinformatics, 36(6), 1896-1901.

Narahashi, T. (2001). Pharmacology of tetrodotoxin. Journal of Toxicology: Toxin Reviews, 20(1), 67-84.
Nieto, F.R., Cobos, E.J., Tejada, M.Á., Sánchez-Fernández, C., González-Cano, R., \& Cendán, C.M. (2012). Tetrodotoxin (TTX) as a therapeutic agent for pain. Marine Drugs, 10(2):281-305.

Noguch, T., \& Arakawa, O. (2008). Tetrodotoxin-distribution and accumulation in aquatic organisms, and cases of human intoxication. Marine Drugs, 6(2), 220-242.

O'Brien, J. J., O'Callaghan, J. P., Miller, D. B., Chalgeri, S., Wennogle, L. P., Davis, R. E., Snyder, G.L., \& Hendrick, J. P. (2020). Inhibition of calcium-calmodulin-dependent phosphodiesterase (PDE1) suppresses inflammatory responses. Molecular and Cellular Neuroscience, 102, 103449.

Papoutsis, K., Zhang, J., Bowyer, M. C., Brunton, N., Gibney, E. R., \& Lyng, J. (2020). Fruit, vegetables, and mushrooms for the preparation of extracts with $\alpha$-amylase and $\alpha$ glucosidase inhibition properties: A review. Food Chemistry, 128119.

Ryan, J. T., Ross, R. P., Bolton, D., Fitzgerald, G. F., \& Stanton, C. (2011). Bioactive peptides from muscle sources: meat and fish. Nutrients, 3(9), 765-791.

Saoudi, M., Abdelmouleh, A., \& El Feki, A. (2010). Tetrodotoxin: a potent marine toxin. Toxin Reviews, 29(2), 60-70.

Sayd, T., Dufour, C., Chambon, C., Buffière, C., Remond, D., \& Sante-Lhoutellier, V. (2018). Combined in vivo and in silico approaches for predicting the release of bioactive peptides from meat digestion. Food Chemistry, 249, 111118.

Schwartz, D. M., Fields, H. L., Duncan, K. G., Duncan, J. L., \& Jones, M. R. (1998). Experimental study of tetrodotoxin, a long-acting topical anesthetic. American Journal of Ophthalmology, 125(4), 481-487.

Sievers, F., Wilm, A., Dineen, D., Gibson, T. J., Karplus, K., Li, W., Lopez R., McWilliam H., Remmert M., Söding J., \& Thompson, J. D. (2011). Fast, scalable generation of highquality protein multiple sequence alignments using Clustal Omega. Molecular Systems Biology, 7(1), 539.

Tadesse, S. A., \& Emire, S. A. (2020). Production and processing of antioxidant bioactive peptides: A driving force for the functional food market. Heliyon, 6(8), e04765.

The UniProt Consortium, (2019). UniProt: a worldwide hub of protein knowledge, Nucleic Acids Res. 47, 506-515.

Tonolo, F., Folda, A., Cesaro, L., Scalcon, V., Marin, O., Ferro, S., Bindoli A., \& Rigobello, M. P. (2020). Milk-derived bioactive peptides exhibit antioxidant activity through the Keap1-Nrf2 signaling pathway. Journal of Functional Foods, 64, 103696.

Ulman, A., Çiçek, B. A., Salihoglu, I., Petrou, A., Patsalidou, M., Pauly, D., \& Zeller, D. (2015). Unifying the catch data of a divided island: Cyprus's marine fisheries catches, 1950-2010. Environment, Development and Sustainability, 17(4), 801-821.

Valencia-Mejía, E., Batista, K. A., Fernández, J. J. A., \& Fernandes, K. F. (2019). Antihyperglycemic and hypoglycemic activity of naturally occurring peptides and protein hydrolysates from easy-to-cook and hard-tocook beans (Phaseolus vulgaris L.). Food Research International, 121, 238-246.

Yaglioglu, D., Turan, C., Erguden, D., \& Gurlek, M. (2011). Range expansion of silverstripe blaasop, Lagocephalus sceleratus (Gmelin, 1789), to the northeastern Mediterranean Sea. Biharean Biologist, 5 (2), 159-161.

Yu, C. F., \& Yu, P. (2002). Are puffer fish more toxic in their spawning seasons? Marine Biology, 140(5), 1053-1057. 
Yu, C. H., (2008). Detection and biosynthesis of puffer fish toxin from bacterial culture for novel medical application. PhD Thesis, (Department of Applied Biology and Chemical Technology, The Hong Kong Polytechnic University, Hong Kong, China).
Zhou, J., Chen, M., Wu, S., Liao, X., Wang, J., Wu, Q., Zhuang M., \& Ding, Y. (2020). A review on mushroom-derived bioactive peptides: preparation and biological activities. Food Research International, 109230. 